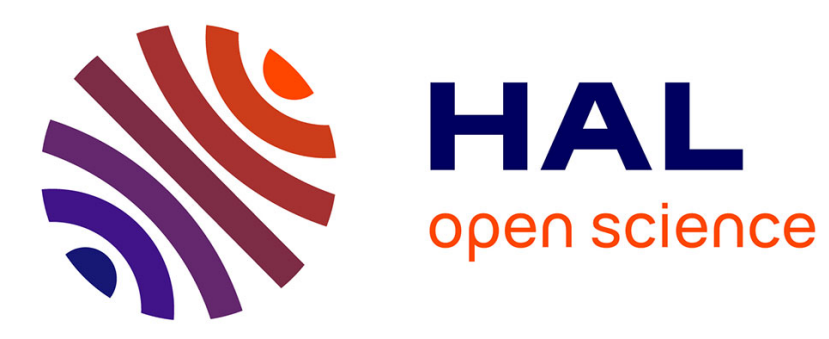

\title{
Rawlsian universalism confronted with the diversity of reality \\ Bernard Bret
}

\section{To cite this version:}

Bernard Bret. Rawlsian universalism confronted with the diversity of reality. Justice spatiale - Spatial justice, 2009, Space and Justice, 1, http://www.jssj.org/article/luniversalisme-rawlsien-confronte-a-ladiversite-du-reel/. halshs-01730105

\section{HAL Id: halshs-01730105 https://shs.hal.science/halshs-01730105}

Submitted on 12 Mar 2018

HAL is a multi-disciplinary open access archive for the deposit and dissemination of scientific research documents, whether they are published or not. The documents may come from teaching and research institutions in France or abroad, or from public or private research centers.
L'archive ouverte pluridisciplinaire HAL, est destinée au dépôt et à la diffusion de documents scientifiques de niveau recherche, publiés ou non, émanant des établissements d'enseignement et de recherche français ou étrangers, des laboratoires publics ou privés. 


\title{
Rawlsian universalism confronted with the diversity of reality
}

\author{
Bernard BRET \\ Translator: Claire Hancock
}

How can we account for the diversity of the world, its multiplicity, and still be able to see humanity's unity through the variety of cultures? How can we assess facts morally when social practices vary through time (history matters) and space (geography matters too)? How can we work beyond a merely empirical approach based on observation, to make sense of what we observe in an intelligible, coherent and rational way?

Clearly, we need a theory which offers an interpretive framework for social organisations and allows an ethical assessment. This paper suggests that John Rawls' thought, as presented in A Theory of Justice ${ }^{1}$, provides such a framework and may enable us to assess on universal grounds as well as understand specific situations.

\section{The apparent incompatibility between universalism and the particular}

The tension between a diverse reality and an abstract concern for universality can be interpreted in several ways. It could reflect the difficulty that arises from trying to concile values specific to different cultural environments. In some views, there should be some shared values one could draw on to avoid conflicts. Others might question that such common values be compatible with the reality principle. These diverse points of view underline the necessity to articulate the universal and the particular.

If Samuel Huntington has drawn our attention to the risk of a "clash of civilizations ${ }^{2}$, it is undeniable that universalism, claimed by some and challenged by others, could well perpetuate the domination of one culture over others: how universal is a moral value if it is not universally accepted as such? This is one of the issues of globalization in our world as it is (and not as it can be imagined in the abstract). Globalization may be understood not only as a process of economic integration through trade, foreign direct investments, the rise of financial instruments and multinational corporations, but also, and this is crucial, as the worldwide spread of certain cultural values and social practices. The asymetric nature of the process reiterates the dependency of the weaker states and people on more powerful ones. In other words, to state a well-known fact, globalization is also a process of Westernisation, though this statement probably needs to be qualified. Indeed it is an equally well-known fact, that hardly needs restating, that globalization also triggers a backlash, a quest for identity that may go as far as cultural isolationnism, a rejection of the other and forms of

${ }^{1}$ RAWLS John, $A$ Theory of Justice, Harvard University Press, 1971.

RAWLS John, Justice et Démocratie, Paris, Le Seuil, coll. La couleur des idées, 1993, 387 p.

RAWLS John, Political Liberalism, New York, Colombia University Press, 1993.

RAWLS John, Justice as Fairness, A restatement, The Belknap Press of Harvard University, 2001.

2 HUNTINGTON Samuel, The Clash of Civilizations and the Remaking of World Order, Simon \& Schuster, 1996. 
religious fundamentalism. This backlash is radicalized if people feel threatened by this universal or humiliated by the strength deployed to bring about their submission to it. All we have then is a particularism maskerading as universal, and imposed as such to other cultures by confrontation or sheer violence.

The world is astir with reactive identities which function as refusals to fall for such a trick. Formerly colonized people aspire to cultural decolonization after gaining political decolonization. Minds need decolonizing as much as countries did, and independence is of little avail if formerly colonized people retain the values of former colonizers, if acculturation has made it impossible for them to return to their cultural roots. But if this « return to the roots " implies a uncritical return to an imagined and reinvented past, is it really a liberation or yet another alienation? While this alienation is self-inflicted, it restricts people to a mythical past which makes it impossible to think ahead into the future. Religious fundamentalism is one instance of this danger, of which the Islamic Revolution in Iran, against the Shah's regime, is illustrative: it was a refusal of a modernization which was felt to betray the culture and promote alien values and ways of life.

Refusing the universal brings one up against a wall: moral and political philosophy, when it posits the universalism of certain values, is denounced as a fruitless intellectual speculation devoid of connexion with reality. Such a posture would indeed be intenable since moral and political thought necessarily has to provide instruments to reflect and act on society. Were it to renounce this objective, the contradiction would be obvious and failure unavoidable.

There is no alternative in accepting one's refusal of the universal and proclaiming moral particularisms. The danger there is relativism and communitarianism. If an ethic were to be groupspecific, then specific social practices would gain normative authority, and acts could be assessed only in reference to the mores of the group in which they take place. That is doubly dangerous: on the one hand, because it tends to legitimize anything on the mere grounds that it exists, and, on the other hand, because it locks an individual into the practices of the place and time where (s)he happens to have been born, and denies his or her freedom. The first risk entails that of conservatism: if ethic is based on what exists, it is therefore right not to change what exists, or to change it only within the limits of what is socially acceptable for the community. Every community has its own boundaries between what is just and injust. But clearly, in holistic societies in which the group is given priority over the individual, collective heritage validates standing practices and confers on them a cultural and moral legitimacy incompatible with the idea of progress. This is beneficial to the strictest conservatism: why change since tradition sanctions what has been until now in conformity with the norms, and since what exists is rooted in the culture and identity of the group ? In this perspective, inequalities in living conditions belong to cultural heritage and, as such, derserve to be preserved. Gender inequality is also legitimate since past norms established it as normal. The line of argument becomes circular, as it claims that something exists because it has reasons to exist and its very existence confers moral legitimacy on it.

Communitarianism thus denies individual freedom and circumscribes each person within the values of his or her own society, which serve the assertion of a collective identity, but not of individual identities.

\section{2. the very diversity of reality makes a universal theory all the more necessary}

We can reverse the reasoning presented above and argue in favour of the necessity of universal values. 
One milestone of such a stance is the universal Declaration of Human Rights put forward in 1948 by the United Nations. In this text of declarative value, member states acknowledged the existence of principles above and beyond their respective legal frameworks. Therefore, the respect for legal hierarchy demands that laws in each country conform to these universal principles. Following Mireille Delmas-Marty ${ }^{3}$, we could see this as a dialectics of ethics and law, since ethics inspire law and law dictates a norm. The ethical qualification of acts inspires their legal qualification and presses in the direction of further recognition of rights by law. Hence a notion such as « crime against humanity ", the result of a process which could be emulated for other crimes or the recognition of other rights. The issue of justice is never far from such processes, since they are opportunities to assert the universalism of certain values.

At this stage, it is important to raise a crucial question: on what grounds can the universal claim legitimacy?

An answer to this question is to be found in the process of enounciation of the principles of justice. A rule grounded in the social practices of a group does not qualify as universally legitimate, not even within that very group. That would be a form of communitarianism and a limit on people's freedom since they would be denied a faculty of judgement. It would be totalitarian to grant such a rule a normative value for other groups, since they would have values imposed on themselves from the outside. In either case, moral autonomy is denied and reason abdicated. The only justification would be the imposition of a transcendent reason: this religious perspective obviously fails the test of universalism since religious belief is not necessarily shared.

How then to think justice and derive principles from it, if not rationally, as John Rawls attempts to do in his Theory of Justice? Much as Kant did when establishing his principles of morals, Rawls aims for principles of justice of universal value, and it is the process whereby they are stated which confers this quality on them. The process is abstract ( My aim is to present a conception of justice which generalizes and carries to a higher level of abstraction the familiar theory of the social contract as found, say, in Locke, Rousseau and Kant ${ }^{4}$ ) and rational process, which Rawls qualifies as "pure procedural justice », which means that the procedure whereby justice is stated is such that it can only produce just principles.

I do not intend to explain Rawls' theory or his method. However, it is necessary to state briefly what makes it universal and why it is fruitful for social sciences, and geography in particular. What founds the universality of Rawls' principles is the " veil of ignorance » between the subject and the real world, in such a way that an " original position » is gained from which to rationally state fair rules for « social partners », that is, rules that will ensure « the appropriate distribution of the benefits and burdens of social cooperation » For Rawls, the best division of material and immaterial goods is the one that serves best the most disadvantaged social partners (maximises the share of those who have the minimum : principle of the maximin). He does not posit that egalitarianism (the equality of all in all aspects of social life) would be the most efficient way to attain that objective. However, he gives priority to the principle of equality over the principle of the maximin, in terms of people's intrinsic value and rights. Rawls's system therefore articulates and establishes a hierarchy between the principle of equality and the principle of difference.

\footnotetext{
${ }^{3}$ DELMAS-MARTY Mireille, Les forces imaginantes du droit. Le relatif et l'universel, Paris, Le Seuil, 2004.

${ }^{4}$ RAWLS John, $A$ Theory of Justice, op. cit. p. 10.
} 
I feel uncomfortable that I have to summarize Rawls's Theory of Justice in a few sentences, and maybe simplify it excessively. But the aim here is not to unfold his theory, just to reflect on his theory's ability to account for the diverse situations of the real world. I will therefore just emphasize this essential point: the universalism of Rawls's principles owes to their rational procedure of enounciation.

Grounding justice on reason and reason alone means the autonomy of the rational being is reasserted, as is his or her place as "social partner " of a human community sharing common values, of which all members are rational beings. The phrase " human community » used here goes against the idea of communitarianism. It emphasizes what all human beings have in common, i.e. reason, rather than the specificity or culture of each or each group. Hence two propositions. The first is inspired by the hierarchy of norms in the legal sphere, according to which an inferior norm cannot contravene to a superior norm. In the moral sphere, social practices specific to each community are legitimate only inasmuch as they do not contravene to universal values of the human community. Confronting the particular to the universal would therefore mimic, in the moral sphere, the conformity check in the legal sphere. The second proposition is that the idea of universalism of values is crucial to the idea of the unity of the human species: that is implicit in the notion of mankind or the phrase used here, " human community ».

\section{Rawlsian universalism makes concrete situations intelligible}

Does Rawlsian universalism enable us to make sense of the diversity of the real world?

While some readings of the Theory of Justice claim that it does not account for real world situations because of its level of abstraction ${ }^{5}$, I posit that its very abstraction confers its universal validity on it. Saying that it is abstract does not mean it comes from nowhere, but means it is a product of reason: it is its very rationality which makes it universal if we accept the idea that human beings, beyond their differences, share a common condition as rational beings, or, to quote Rawls himself, moral persons. Because principles of justice have a rational grounding, they can be used in reasoning. Assessing real-world situations with a concern for principles of justice therefore does not mean measuring the departure between the real and imposed norms, as would be the case in a situation of moral heteronomia, but measuring the world up to the rationality that the human community holds collectively and in each of its members.

One could object that John Rawls himself is a product of his specific culture, and that, according to some of his critics, his theory is not independent from the time and place in which it was formulated, but shaped by the specific values of his own background. Rawls would therefore merely be echoing social-democratic values, and by no means producing a universal theory. While it is true that social democracy is probably the most adequate form of social contract to implement Rawlsian principles today, that does not necessarily imply that his system is a by-product of social democracy, or that other forms of social or political organisation could not, in different conditions, prove to be more conform to Rawlsian principles.

${ }^{5}$ SANDER Michael, Liberalism and the Limits of Justice, Cambridge, University Press, 1982

WALZER Michael, Spheres of Justice, A Defense of Pluralism and Equality, Oxford, Blackwell, 1983. 
To ground one's work in those principles is therefore not a contribution to the Westernization of the world: it shows concern for the compatibility of the particular and the universal. The object is not to measure the distance between non-Western civilizations and a Western civilization set up as a model. It is to measure the gap between real-world practices and the principles of justice as fairness everywhere, including in the Western world.

\section{Rawlsian universalism enables real-world action}

Understanding the world is all very well. There is however a responsability on the part of intellectuals to change it too, not by abandoning their role as intellectuals, but by playing it fully: thought produces understanding, but this understanding induces actions on things, on people and places, in the case of specialists of space such as geographers. What then can we derive from the notion of justice as fairness that could be an inspiration for action? Is it in fact useless, and are John Rawls's hands clean because he has no hands, as was once quite unfairly said of Immanuel Kant? It will be clear by now that such is not my belief. Quite otherwise: I argue that precisely because the Theory of Justice is abstract and not based on any real-world situation, it can apply to all real-world situations. Furthermore, one test of the theory's intellectual validity is its efficiency in furthering universalism in the world.

The matter is, no less, to order pluralism in conformity with the universal. It becomes necessary to choose the lesser of two evils: one that would consist of respecting universal principles without taking cultural realities into account, the other of giving up on the universal in the name of cultural diversity. But arbitrating between the two must remain a dynamic process and aim to submit reality to universal principles, even if we know it is virtually impossible. Reality as transformed in direction of universal values tends towards justice as fairness along an asymptotic curve: John Rawls's theory may be considered as an utopia, but a positive utopia, which shows a path to improvement for world organization, without providing ready-made solutions, and which calls for public debate. Establishing a dialogue between civilizations is probably the most plausible method, because principles of justice take multiple forms in different cultural contexts, and because considering social partners as rational beings implies they are able to find a consensus by a convergence between initial positions.

In other words, understanding the world and transforming it are two sides of the same coin in Rawls' philosophy. He distinguishes the good and the right by defining good as what a rational being can hope for and right as what is in conformity with principles of justice enounciated through a rational procedure. It is therefore logical to consider the right as good since the right gives a satisfaction which is a good. The priority of the right over the good ( "in justice as fairness, the concept of right is prior to that of the good" ${ }^{6}$ ) means both are related, through the happiness a rational being derives from acting in conformity with reason.

What matters therefore is to connect the understanding of the world with action in the real world, the sphere of thought and that of the political: how indeed could one act on a world one does not understand, and how not to act if the understanding of the world shows it is dysfunctional with regard to what one's reason perceives as fair?

\footnotetext{
${ }^{6}$ RAWLS John : A Theory of Justice, op. cit, p. 347.
} 
So what can geography gain from the Theory of Justice, if we bear in mind that John Rawls never mentions space, but that such a sharp thought is bound to prove useful in all fields of knowledge and action? One important aspect of justice as fairness is the idea of optimizing inequalities to benefit the poorest: maximize the share of those who have the minimum, the principle of difference summarizing in the word maximin. Peoples and their talents being diverse, there are inequalities which produce justice in the sense that they contribute to the welfare of the deprived more than egalitarianism would. It is important to clarify the fact that while this is both possible and desirable, it is hardly ever the case, and inequalities in the real world are mostly injust because they do not conform to the principle of the maximin. It is also important to reassert the first principle of justice, which is the equal dignity of social partners as rational beings, and which is therefore, as stated above, a principle of equality.

For geography, which deals with spatial differentiations (as a form of knowledge), and for planning, whose object is to transform space to conform to a social project (it is a policy), the Theory of Justice proves a fruitful basis. It allows to think the diversity of the real world, and first and foremost inequalities in levels of development. The issue which arises is the following: are these inequalities injustices, and, if so, does the principle of redress apply to them ? We cannot expand on this aspect here, but let us posit that inequalities are not a mere by-product of the development process, but that development is necessarily inequal, as the term itself suggests ${ }^{7}$. This hypothesis mades it possible to understand some spatial inequalities as right while others are wrong. The core-periphery model ${ }^{8}$ provides a useful way of reading inequalities, and also to define planning objectives likely to produce justice. The question boils down to this: does the core lead its periphery in a dynamics of development of which inhabitants of the periphery benefit (in which case the inequality is right), or do we have an exploitation of the periphery by the core, depriving it of its resources, its production factors and reducing it to inefficiency (in which case inequality is wrong)? In view of the complexity of reality, this way of putting things may appear simplistic, but one could also argue that, the more complex the reality, the more one needs simple principles on which to base ones reasoning, to avoid getting lost. The same applies for planning: because it is a complex policy, a clear objective must be defined (to produce justice), to avoid losing one's compass.

Additional difficulty derives from geographic discontinuities, such as frontiers. Sharing the benefits and burdens of social cooperation is difficult in a world fragmented by state limits which create territories with each their own legislations in fiscal, social and environmental areas. Within states the same questions arise, with limits between territorial units, some with a large autonomy for setting their own rules. There is therefore no consistency between the scales of benefits and the scales of burdens. A risk is that those limits be used to internalize benefits and externalize burdens: an apparent justice could be produced benefitting integrated peripheries, while costs fall on exploited peripheries. Is that the case in the current situation? There are too many debates surrounding that question. But merely asking it points in one possible direction: could the relative well-being of the working-classes in countries of the global North be paid for in part by the exploitation of countries of the global South? This question is very sensitive, and we must beware of instrumentalizing territories and of exonerating the ruling classes of countries of the North of their responsibilities. It

${ }^{7}$ SEN Amartya, Development as Freedom, Alfred Knopf Inc, 1999.

SEN Amartya, Repenser l'inégalité, Paris, Le Seuil, 2000, 287 p.

${ }^{8}$ REYNAUD Alain, Société, espace et justice, Paris, PUF, 1981, $263 \mathrm{p}$ 
is however a question that must be addressed in order to understand what is at play between the social and the spatial; only then will we be able to delineate what is at stake, measure the forces in presence, formulate a project and define political alliances.

The diversity of the world goes further than inequalities in development: cultural differences also challenge universalism. The Theory of Justice deals with this, by combining a respect for cultural difference with action in favour of justice, though the application of principles is always difficult and sometimes impossible: but the reality principle should not overcome principles of justice.

\section{Conclusion}

Many other aspects of the Theory of Justice deserve to be addressed, since it is as manifold as the world is complex and riven with injustice! By no means did this paper aim to be comprehensive, just to open up a few questions and strands of thought. It mentioned space, but we should probably also mention, following John Rawls, the importance of time. Justice can only be understood in all its dimensions, the historic dimension as well as the social dimension and spatial dimension. The idea of sustainability is crucial to environmental justice through time. Produced by a reason deliberately abstracted from reality, justice as fairness encounters people, their histories, their territories and proves to be theory which can account for the world, and because it is rational, can also transform it.

About the author: Bernard BRET, UMR 5600 Environnement, Ville, Société, Université Lyon 3 Jean Moulin

To quote this article: Bernard BRET, "L'universalisme rawlsien confronté à la diversité du réel » ["Rawlsian universalism confronted with the diversity of reality", traduction: Claire Hancock] justice spatiale | spatial justice | nº1 septembre | september 2009 | http://www.jssj.org 